\title{
The Phorbol Ester Fraction from Jatropha curcas Seed Oil: Potential and Limits for Crop Protection against Insect Pests
}

\author{
Alain Ratnadass ${ }^{1, *}$ and Michael Wink ${ }^{2}$ \\ 1 Cirad, HortSys Research Unit, TA B-103/PS4, F-34398 Montpellier Cedex 5, France \\ 2 Institute of Pharmacy \& Molecular Biotechnology (IPMB), Heidelberg University, \\ Im Neuenheimer Feld 364, D-69120 Heidelberg, Germany; E-Mail: wink@uni-hd.de \\ * Author to whom correspondence should be addressed; E-Mail: ratnadass@cirad.fr; \\ Tel.: +33-467-593-114; Fax: +33-467-615-688.
}

Received: 24 September 2012; in revised form: 23 November 2012 / Accepted: 27 November 2012 / Published: 30 November 2012

\begin{abstract}
The physic nut shrub, Jatropha curcas (Euphorbiaceae), has been considered as a "miracle tree", particularly as a source of alternate fuel. Various extracts of the plant have been reported to have insecticidal/acaricidal or molluscicidal/anthelminthic activities on vectors of medical or veterinary interest or on agricultural or non-agricultural pests. Among those extracts, the phorbol ester fraction from seed oil has been reported as a promising candidate for use as a plant-derived protectant of a variety of crops, from a range of pre-harvest and post-harvest insect pests. However, such extracts have not been widely used, despite the "boom" in the development of the crop in the tropics during recent years, and societal concerns about overuse of systemic chemical pesticides. There are many potential explanations to such a lack of use of Jatropha insecticidal extracts. On the one hand, the application of extracts potentially harmful to human health on stored food grain, might not be relevant. The problem of decomposition of phorbol esters and other compounds toxic to crop pests in the field needing further evaluation before such extracts can be widely used, may also be a partial explanation. High variability of phorbol ester content and hence of insecticidal activity among physic nut cultivars/ecotypes may be another. Phytotoxicity to crops may be further limitation. Apparent obstacles to a wider application of such extracts are the costs and problems involved with registration and legal approval. On the other hand, more studies should be conducted on molluscicidal activity on slugs and land snails which are major pests of crops, particularly in conservation agriculture systems. Further evaluation of toxicity to natural enemies of insect pests and studies on other beneficial insects such as pollinators are also needed.
\end{abstract}


Keywords: Physic nut; plant-derived insecticide; mode of action; field pests; crop pests

\section{Introduction}

\subsection{Jatropha curcas as a "Miracle Tree"}

The physic nut shrub, Jatropha curcas (Euphorbiaceae), has been considered as a "miracle tree", particularly as a source of alternate fuel, since seed oil can be used as a substitute to diesel oil [1-7]. Besides its production for this use (which "boomed" in recent years), the shrub is grown as live hedges to combat erosion, or as live fences to protect market gardens from domestic animals [8]. This adds to the more or less traditional use of the shrub for other purposes, particularly as medicines, in many parts of the world [9].

\subsection{Biocidal Effects of J. curcas Extracts}

Besides effect on human pathogens [10,11], various extracts of the plant have been reported to have insecticidal/acaricidal or molluscicidal/anthelminthic activities on vectors of medical or veterinary interest or on non-agricultural pests. These encompass mosquitoes [12-17], mites [18,19], cockroaches [20], houseflies [21], termites [22-25], and water snails hosts of human or cattle parasites (especially schistosomes) [26-34].

Toxicity of extracts of other species of Jatropha (e.g., J. gossypifolia or J. podagrica) has also been reported $[35,36]$.

Among $J$. curcas extracts, the main biocidal action has been ascribed to the phorbol ester (tetracyclic diterpenoid) fraction [37,38] from seed oil. Six phorbol esters (Jatropha factors C1-C6) have been characterized from $J$. curcas seed oil with the molecular formula $\mathrm{C}_{44} \mathrm{H}_{54} \mathrm{O}_{8} \mathrm{Na}_{\text {a }}$, as intra-molecular diesters of the same diterpene, 12-deoxy-16-hydroxyphorbol. Biocidal, including insecticidal activity of phorbol esters is due to the stimulation of the cellular target protein kinase $\mathrm{C}$ (PKC). Toxic phorbol esters are also found in other genera of the Euphorbiaceae family, particularly Croton and Euphorbia [39]. This fraction has also been reported as a promising candidate for use as a plant-derived protectant of a variety of crops, from a range of pre-harvest and post-harvest insect pests.

On the other hand, the physic nut tree is also subject to damage by several pests [40-43], but these insects are often specialists which are adapted to the toxicity of their host plant. Some specialists, such as the aposematic Pachycoris klugii (Hemiptera) may even sequester phorbol ester as chemical defense means against predators [44]. A few varieties of J. curcas, which have been selected by plant breeders, do not accumulate phorbol esters; the seed oil is no longer toxic to animals [37]. Seeds also contain a toxic lectin (a peptide) which however does not appear in the pressed oil [37].

The aim of this review is to take stock of all reported work on the insecticidal effect of physic nut (particularly J. curcas) and its extracts (particularly the oil and its phorbol ester fraction) on crop pests, and analyze the reasons for the lack of practical applications of the acquired knowledge, notably its translation into commercial products. 


\section{Insecticidal Activity of $J$. curcas Extracts (Particularly Phorbol Esters) on Pre- and Post-Harvest Crop Pests}

\subsection{Crops Studied}

There are 10 crops on which $J$. curcas extracts have shown potential for protection against insect pests (Table 1).

Field crops encompass cotton [45,46], cowpea [47,48], maize [49], musk melon [50], okra [51], rice [50,52,53], and sorghum [54].

Stored crops encompass bean seeds [55], cowpea seeds [56], maize grain [57-59], mungbean seeds [46], potato tubers [60,61], rice grain [62,63], and wheat grain [64].

It should however be noted that not all studies involved relevant control/blanks to make sure that reported effects were due to the extracts, and not the solvents (e.g., [50], as opposed to [47]).

Table 1. Crops on which Jatropha curcas extracts have shown potential as field or storage protectants.

\begin{tabular}{|c|c|c|c|c|c|}
\hline Types of crops & Crop species & Field & Storage & Type of application & References \\
\hline \multirow[t]{5}{*}{ Cereals } & Maize (Zea mays) & $\mathrm{X}$ & & Oil emulsion & [49] \\
\hline & & & $\mathrm{X}$ & $\begin{array}{l}\text { Emulsifiable concentrate of seed oil; } \\
\text { leaf extracts; seed oil }\end{array}$ & {$[46,57-59]$} \\
\hline & Rice (Oryza sp.) & $\mathrm{X}$ & & $\begin{array}{l}\text { Seed oil: methanol, petroleum ether, } \\
\text { ethyl acetate, benzene and water extracts; } \\
\text { seed powder: acetone and aqueous extract; } \\
\text { formulated seed oil }\end{array}$ & {$[50,52,53]$} \\
\hline & & & $\mathrm{X}$ & Seed powder; seed powder acetone extract & {$[62,63]$} \\
\hline & Sorghum (Sorghum bicolor) & $X$ & & $\begin{array}{l}\text { Emulsifiable concentrate of seed oil } \\
\text { methanol extract }\end{array}$ & {$[54]$} \\
\hline \multirow[t]{4}{*}{ Legumes } & Bean (Phaseolus aconitifolius) & & $\mathrm{X}$ & Seed oil & {$[55]$} \\
\hline & Cowpea (Vigna unguiculata) & $\mathrm{X}$ & & Emulsifiable concentrate of seed oil & {$[47,48]$} \\
\hline & & & $\mathrm{X}$ & Seed oil & {$[56]$} \\
\hline & Mungbean (Vigna radiata) & & $\mathrm{X}$ & Emulsifiable concentrate of seed oil & {$[46]$} \\
\hline Tuber & Potato (Solanum tuberosum) & & $\mathrm{X}$ & Seed oil & {$[60,61]$} \\
\hline \multirow[t]{2}{*}{ Fruits/vegetables } & Melon (Cucumis melo) & $\mathrm{X}$ & & $\begin{array}{l}\text { Seed oil: methanol, ethanol, petroleum ether, } \\
\text { ethyl acetate, benzene and water extracts }\end{array}$ & {$[50]$} \\
\hline & Okra (Abelmoschus esculentus) & $\mathrm{X}$ & & Aqueous and petroleum ether extracts & {$[51,65]$} \\
\hline Fibre & Cotton (Gossypium spp.) & $\mathrm{X}$ & & Emulsifiable concentrate of seed oil & {$[45,46,66]$} \\
\hline
\end{tabular}

\subsection{Crop Pests Studied}

There are 37 insect pest species against which $J$. curcas extracts have been employed, and have shown biological activity (Table 2). 
Table 2. Insect pest species which were affected by Jatropha curcas extracts.

\begin{tabular}{|c|c|c|c|}
\hline Order & Family & Species & References \\
\hline \multirow[t]{13}{*}{ Coleoptera } & Bostrychidae & Rhyzopertha dominica & [67] \\
\hline & \multirow{2}{*}{ Bruchidae } & Callosobruchus chinensis & [46] \\
\hline & & Callosobruchus maculatus & {$[55,56,68-70]$} \\
\hline & \multirow{5}{*}{ Chrysomelidae } & Phaedon cochliariae & [71] \\
\hline & & Podagrica sjostedti & [67] \\
\hline & & Podagrica uniforma & [67] \\
\hline & & Podagrica sp. & [51] \\
\hline & & Sitophilus zeamais & {$[46,57-59,62,63,67,69]$} \\
\hline & \multirow[t]{2}{*}{ Curculionidae } & Sitophilus granarius & {$[64]$} \\
\hline & & Amorphoidea lata & [65] \\
\hline & Silvanidae & Oryzaephilus surimanensis & [67] \\
\hline & \multirow{2}{*}{ Tenebrionidae } & Tribolium confusum & [68] \\
\hline & & Tribolium castaneum & [67] \\
\hline \multirow[t]{11}{*}{ Hemiptera } & \multirow[t]{5}{*}{ Aphididae } & Myzus persicae & [72] \\
\hline & & Lipaphis erysimi & [73] \\
\hline & & Aphis fabae & [48] \\
\hline & & Aphis craccivora & [48] \\
\hline & & Aphis gossypii & [66] \\
\hline & \multirow{2}{*}{ Cicadellidae } & Amrasca biguttula & [46] \\
\hline & & Empoasca sp. & [47] \\
\hline & \multirow[t]{2}{*}{ Coreidae } & Anoplocnemis curvipes & [48] \\
\hline & & Clavigralla tomentosicollis & [47] \\
\hline & Delphacidae & Sogatella furcifera & [53] \\
\hline & Miridae & Eurystylus oldi & [54] \\
\hline \multirow[t]{12}{*}{ Lepidoptera } & Crambidae & Cnaphalocrocis medinalis & [50] \\
\hline & \multirow[t]{2}{*}{ Gelechiidae } & Pectinophora gossypiella & {$[45,66]$} \\
\hline & & Phthorimea operculella & {$[60]$} \\
\hline & \multirow[t]{5}{*}{ Noctuidae } & Busseola fusca & {$[74,75]$} \\
\hline & & Helicoverpa armigera & {$[45,46,50,54,66]$} \\
\hline & & Helicoverpa zea & {$[76]$} \\
\hline & & Sesamia calamistis & {$[74,75]$} \\
\hline & & Spodoptera frugiperda & {$[72,77]$} \\
\hline & Pieridae & Pieris rapae & {$[78]$} \\
\hline & Pyralidae & Mussidia nigrivenella & [49] \\
\hline & Sphingidae & Manduca sexta & {$[72,79]$} \\
\hline & Plutellidae & Plutella xylostella & {$[72]$} \\
\hline Orthoptera & Acrididae & Zonocerus variegatus & [73] \\
\hline Thysanoptera & Thripidae & Megalurothrips sjostedti & {$[47,48]$} \\
\hline
\end{tabular}

Coleoptera were the most represented, with 13 species in six families, encompassing mainly stored grain-feeding beetles [22,46,55-59,62-64,67-71,80], flea beetles [51,65,72] and a flower weevil [81].

Lepidoptera were the second most represented order, with 12 species in seven families, encompassing stem boring and leaf-feeding caterpillars [50,52,72,74,75,77-79], fruit or head-feeding caterpillars $[45,46,49,50,54,66,72,76]$, and the potato tuber moth [60]. 
They were followed by sap-feeding piercing-sucking Hemiptera, with 11 species in five families $[46-48,53,54,66,72,73,78]$. Two studies showed activity on a flower thrips $[47,48]$, and one a grasshopper species [82].

\subsection{Types of Extracts and of Effects}

Extracts that were studied and showed biological activity against insect pests of crops were mainly oil extracts, particularly phorbol esters (Table 3). Range of biocidal/biostatic pathways is quite broad (Table 3), encompassing contact toxicity on all developmental stages, ingestion toxicity, feeding deterrency and repellency (Table 3).

Table 3. Types of extracts evaluated and types of effects highlighted in reported studies.

\begin{tabular}{|c|c|c|}
\hline Type of extract & Reported type of effect & Reference \\
\hline Aqueous extract & $\begin{array}{l}\text { Contact toxicity and partial chemo-sterilizing effect; } \\
\text { delayed molting; } \\
\text { morphogenetic lethal effect after topical application; } \\
\text { chronic toxicity }\end{array}$ & [66] \\
\hline Leaf extracts & $\begin{array}{l}\text { inhibition of oviposition, } \\
\text { anti-feedent and insecticidal effects }\end{array}$ & [58] \\
\hline Dry seed powder acetone extract & Contact toxicity, ingestion toxicity & [63] \\
\hline Dry seed powder and water extract & Repellency and reduced emergence & [69] \\
\hline $\begin{array}{l}n \text {-Hexane, ethyl acetate and } \\
\text { methanol extracts from dry seed } \\
\text { powder }\end{array}$ & Feeding deterrency & [76] \\
\hline Seed oil & Anti-oviposition and ovicidal effects & {$[64]$} \\
\hline Seed oil & Egg mortality & {$[55]$} \\
\hline Seed oil & Contact toxicity & [72] \\
\hline Seed oil & Antioviposition and ovicidal effects & {$[56]$} \\
\hline Seed oil & Feeding deterrency & {$[73]$} \\
\hline Seed oil & Oviposition deterrency and ovicidal effects & [49] \\
\hline Seed oil & Feeding deterrency & [74] \\
\hline Seed oil & Repellency and egg toxicity & {$[70]$} \\
\hline Seed oil & Insect growth regulatory effect & [23] \\
\hline Oil and ethanol extract & Contact toxicity & [73] \\
\hline Oil and methanol extract & Reduction of amylase and LDH activities & {$[50]$} \\
\hline Oil and phorbol esters & Cessation of growth and development & {$[72,79]$} \\
\hline Oil and phorbol esters & $\begin{array}{l}\text { Contact toxicity, ingestion toxicity, ovicidal effects } \\
\text { and reduction of development/fertility of progeny }\end{array}$ & [54] \\
\hline Phorbol esters & Stomach toxicity and antifeeding activity & [78] \\
\hline Phorbol esters & $\begin{array}{l}\text { Contact toxicity; reduction of food consumption, } \\
\text { relative growth and food conversion efficiency }\end{array}$ & [77] \\
\hline
\end{tabular}

The most studied pest family has been that of Noctuidae, with 10 studies on 5 species (at par with Aphididae, but with only 4 studies on the latter). Noctuid caterpillars were either leaf feeding, stem 
boring, or fruit boring species, and were studied mainly in the laboratory, although some field tests on Helicoverpa armigera were conducted on cotton [22] and musk melon [50].

For $H$. armigera on cotton, synthetic insecticides were more effective than Jatropha oil (at the dose of $800 \mathrm{~mL} \mathrm{ha}^{-1}$ ) at the start of treatment, as the oil affects only insect growth and its effect is therefore slower. On musk melon, a 70\% reduction of infestation over the control was observed with a concentration of $0.5 \mathrm{mg} \mathrm{mL}^{-1}$ of methanol extract of Jatropha oil (dosage per ha not known).

As concentrations of phorbol esters in one of the studies on $H$. armigera [54] were actually mistakenly reported in $\mathrm{g} \mathrm{mL}^{-1}$ instead of $\mathrm{mg} \mathrm{mL}^{-1}$, in all laboratory studies, effective concentrations either for contact or ingestion deterrency/toxicity effect were consistently in the range between 0.1 and $1 \mathrm{mg} \mathrm{mL}^{-1}$ of phorbol esters (or their equivalent in oil).

However, one should be cautious concerning the efficiency of such extracts under field conditions, as translated by the little numbers of actual field tests. In addition, species with cryptic caterpillars like stem borers, particularly Sesamia calamistis, which does not have any wandering larval stage, and fruit worms (e.g., Helicoverpa spp.) are more difficult to control than leaf-feeding species. Foliar spraying targeting the latter (e.g., Spodoptera frugiperda) may on the other hand result in phytotoxicity on the crop (namely leaf burns), not necessarily due to phorbol esters per se, but to the oil or adjuvants in some formulations $[22,47]$.

\section{Lack of Development of Biocidal (Particularly Crop Pest Insecticidal) Applications of J. curcas Extracts and Potential Explanations}

Since the first records of Jatropha oil biocidal activities on crop insect pests, almost thirty years ago, such extracts have not been widely used, despite the "boom" in the development of the crop in the tropics for biodiesel purpose during recent years, and increased public awareness of adverse environmental impacts of synthetic chemical insecticide use.

Phorbol esters activate PKC [39]. PKC is involved in several cellular signaling pathways. Some of them are active in cancer cells. If PKC is activated in cancer cells, their growth can be stimulated. Because of this property toxicologist classify phorbol esters as "co-carcinogens" or tumor-promoting. This term is somewhat misleading to the non-toxicologists, because it is easily mistaken for a carcinogen which can cause cancer. It should be remembered, that also estrogens, which are the active ingredients of anti-baby pills, have been classified as co-carcinogens because they stimulate growth of hormone-dependent cancer cells. The co-carcinogenic property of phorbol esters should not be an apriori "no-go" for a registration.

Such a lack of use was also reported for other plant-derived insecticides, deterrents, and repellents [83,84]. The main barriers to commercialization for botanical insecticides include: sustainability of the botanical resource, standardization of chemically complex extracts, and regulatory approval. The latter process is as cumbersome and expensive for a botanical insecticide as for a synthetic compound. Because it is difficult or even impossible to obtain patents for such phorbol ester extracts, agrochemical companies are not inclined to spend large amounts of money for toxicological tests and efficacy trials that are required for registration and approval as biopesticides. 


\subsection{High Variability of Phorbol Ester Content and Difficulty of Extraction}

High variability of phorbol ester content and hence of insecticidal activity among physic nut cultivars/ecotypes [37] may be an explanation. This however can be solved by extraction/concentration, but this is not easy to achieve at the village level [75].

The analysis of phorbol esters requires sophisticated laboratory equipment such as HPLC and LC-MS [37,72], which is often lacking in tropical countries or in agricultural laboratories. Therefore, the selection of high-yielding varieties is difficult and labor-extensive. Furthermore, most emphasis in breeding of physic nuts was on the selection of varieties which were low on phorbol esters so that they could be used for animal or human consumption.

\subsection{Non-Relevance of Application on Stored Grain}

Another reason for the lack of development of pesticide uses might be the relevance of the application of such toxic extracts [39] on stored grain aimed at human consumption (Table 1). The fact that most studies refer to such post-harvest pests as Callosobruchus maculatus or Sitophilus zeamais (Table 2) is probably just an indication that these pests are easier to study than field pests, and that use of botanicals on stored produce is a traditional practice, more than on field crops.

On the other hand, human toxicity is mainly ascribed to the curcin protein which occurs in the seed meal but not in the oil. Seed oil also contains hydrogen cyanide. While phorbol esters, as co-carcinogenic (and not carcinogenic per se) compounds [39], are considered as less of a problem, although concentrated solutions are irritant to skin and eyes. Another problem could be toxicity of the extracts against germinating plants (phytotoxicity). At least, if cereal grains are used as seeds, their germination is not affected ruling out a phytotoxic effect of phorbol esters at this level [57].

\subsection{Lack of Studies under Real Conditions}

On both storage and field pests, studies were mainly conducted under laboratory conditions, so that potential field problems such as efficiency and persistence under natural conditions, phytotoxicity on crops (either of the oil, or of adjuvants in phorbol ester formulations [22,47]), and environmental fate, remain to be studied.

The problem of decomposition of phorbol esters and other toxic compounds in the field (from UV light and/or microbes) needs further evaluation before insecticidal or molluscicidal oil extracts can be widely used. This fact may actually also be a partial explanation to their lack of use. On the other hand, recent results showed that phorbol esters are biodegradable in the soil [85].

Further to the case of storage pests, this is another instance of conflicting effects between biological/biocidal activity against pests and persistence/innocuity for humans and the environment. Biodegradability and low persistence in the soil are a plus regarding human health and pollution, but a minus regarding bioactivity on soil pests (e.g., nematodes, on which there are several reports of bioactivity of Jatropha extracts, particularly oil seed cake [86-88]). A trade-off/balance has therefore to be found.

Regarding effects on non-target arthropods, low toxicity of extracts of other species of Jatropha was reported on beneficial insects or mites, namely predators $[89,90]$, while conflicting results were 
obtained with $J$. curcas extracts on parasitoids [70]. On the other hand, in a field study, the better cotton yield with Jatropha oil treatment over farmer conventional practice was ascribed to the innocuity of oil for natural enemies [22].

In any case, further to studies on evaluation of toxicity to natural enemies of insect pests, such studies on other beneficial insects like pollinating insects and honeybees are still needed [91].

\section{Conclusions}

\subsection{Prospects for the Development of J. curcas Extract Uses for Crop Protection}

All the studies discussed indicate that extracts from Jatropha spp. (and particularly J. curcas) leaves, seeds and oil are repellent, deterrent or toxic, either by contact or ingestion, to several agricultural insect pests. The extracts involved mainly contain toxic diterpenes (particularly phorbol esters).

While the development of Jatropha cultivation for its mere insecticidal properties is unlikely, insecticidal compounds such as phorbol esters can be valuable by-products wherever the plant is grown as live-hedges or garden fences, or for biodiesel. As a biofuel (biodiesel), Jatropha has the highest potential in isolated or land-locked countries (e.g., small islands or Sahelian countries), where it has a clear comparative advantage over imported fossil fuels.

As mentioned above, in these contexts, phorbol ester extracts could be obtained as a rather cheap by-product of biodiesel production and would be available in developing countries which cannot afford to buy expensive agrochemicals. Furthermore, these nonrenewable chemical plant protection products are under threat of being banned anyway, due to their documented adverse effects on human health and the environment.

The extraction of the phorbol ester fraction of the seed oil of $J$. curcas using for example methanol as a solvent, does not affect its biodiesel properties [92], so that a small part of oil could be enriched with phorbol esters and used as a plant-derived insecticide. Such a "detoxification" could also help other uses, including as edible oil. Actually, such an "enrichment" would probably be the best trade-off [31], since these compounds are protected from heat when they are in oil, while their shelf-life is considerably reduced when they are extracted [93].

It should however be noted that such extraction/enrichment processes are not possible at the farmer level since it involves the use of solvents e.g. methanol, but could still be done at the village level at a semi-centralized scale (e.g., that of the village power plant) [75].

\subsection{Potential for Combination of Jatropha Extracts with Other Control Options in Integrated Pest} Management (IPM) or Agroecological Strategies

In view of its at least partial effects on crop pests, application of Jatropha oil or its phorbol ester fraction could be complementary with other control methods such as impregnated nets [94]. Actually, such a technique should be cost-effective on high-value crops such as vegetables or "concentrated" products such as or stored produce.

Furthermore, the reported antifungal properties of Jatropha extracts [95-101] could make it for the potential increased fungal infection risk due to microclimate alteration (higher humidity) under such nets. 
Another option would be to combine the biocidal activity of Jatropha extracts and the use of trap plants, in a "push-pull" strategy, as we discussed earlier [54].

The phorbol ester fraction could also be combined with other botanical pesticides (see [83] for a review) that attack different molecular targets in pest organisms. Phorbol esters mainly activate PKC [72] and related signal transduction pathways. Their combination with a neurotoxin (e.g., nicotine, lupin alkaloids: [83]) might result in a synergistic efficacy. In synergistic combinations the dose of the individual component can be reduced, thus minimizing adverse effects, while delaying the emergence of resistant pest strains.

On the other hand, due to its documented toxicity on water snails hosts of human or cattle parasites [26-31], or agricultural pests [22], more studies should be conducted on molluscicidal activity on slugs and land snails which are major pests of crops in conservation agriculture [102], where risk of phytotoxicity and leaching is low, the product being applied on the (thick) mulch [103,104].

Broadly speaking, based on the existing literature and in view of the likely development of Jatropha cultivation in the tropics, the study of the insecticidal effects of its seed oil, particularly phorbol esters, and their evaluation in real conditions, should be given priority, rather than screening of novel active bioactive substances.

\section{References}

1. Heller, J. Physic Nut. Jatropha curcas L. Promoting the Conservation and Use of Underutilized and Neglected Crops. Institute of Plant Genetics and Crop Plant Research (IPGRI), Gatersleben/International Plant Genetic Resources Institute: Rome, Italy, 1996; p. 66.

2. Jongschaap, R.E.E.; Corré, W.J.; Bindraban, P.S.; Brandenburg, W.A. Claims and facts on Jatropha curcas L. Global Jatropha curcas evaluation, breeding and propagation programme. Available online: http://library.wur.nl/way/bestanden/clc/1858843.pdf (accessed on 15 July 2012).

3. Kumar, A.; Sharma, S. An evaluation of multipurpose oil seed crop for industrial uses (Jatropha curcas L.): A review. Ind. Crops Prod. 2008, 28, 1-10.

4. Debnath, M.; Bisen, P.S. Jatropha curcas L., A multipurpose stress resistant plant with a potential for ethnomedicine and renewable energy. Curr. Pharm. Biotechnol. 2008, 9, 288-306.

5. Ye, M.; Li, C.; Francis, G.; Makkar, H.P.S. Current situation and prospects of Jatropha curcas as a multipurpose tree in China. Agroforest. Syst. 2009, 76, 487-497.

6. Brittaine, R.; Lutaladio, N. Jatropha: A smallholder bioenergy crop; the potential for pro-poor development. Available online: http://www.fao.org/docrep/012/i1219e/i1219e.pdf (accessed on 23 November 2012).

7. Islam, A.K.M.A.; Yaakob, Z.; Anuar, N. Jatropha: A multipurpose plant with considerable potential for the tropics. Sci. Res. Essays 2011, 6, 2597-2605.

8. Openshaw, K. A review of Jatropha curcas: An oil plant of unfulfilled promise. Biomass Bioenergy 2000, 19, 1-15.

9. Wink, M.; van Wyk, B.E. Mind-Altering and Poisonous Plants of the World; Timber Press: Portland, OR, USA, 2008.

10. Arekemase, M.O; Kayode, R.M.O.; Ajiboye, A.E. Antimicrobial activity and phytochemical analysis of Jatropha curcas plant against some selected microorganisms. Int. J. Biol. 2011, 3, 52-59. 
11. Thomas, O.O. Re-examination of the antimicrobial activities of Xylopia aethiopica, Carica papaya, Ocimium gratissimum and Jatropha curcas. Fitoterapia 1989, 60, 147-161.

12. Karmegam, J.; Sakthivadivel, M.; Daniel, T. Indegenous plant extracts as larvicidal agents against Culex quinquefasciatus say. Bioresour. Technol. 1996, 59, 137-140.

13. Rahuman, A.A.; Gopalakrishnan, G.; Venkatesan, P.; Geetha, K. Larvicidal activity of some Euphorbiaceae plant extracts against Aedes aegypti and Culex quinquefasciatus (Diptera: Culicidae). Parasitol. Res. 2008, 102, 867-873.

14. Sakthivadivel, M.; Daniel, T. Evaluation of certain insecticidal plants for the control of vector mosquitoes vis. Culex quinquefaciatus, Anopheles staphensi and Aedes aegypti. Appl. Entomol. Zool. 2008, 43, 57-63.

15. Aina, S.A.; Banjo, A.D.; Lawal, O.A.; Jonathan, K. Efficacy of some plant extracts on Anopheles gambiae mosquito larvae. Acad. J. Entomol. 2009, 2, 31-35.

16. Cantrell, C.; Ali, A.; Duke, S.O.; Khan, I. Identification of mosquito biting deterrent constituents from the Indian folk remedy plant Jatropha curcas. J. Med. Entomol. 2011, 48, 836-845.

17. Zewdneh, T.; Mamuye, H.; Asegid, T.; Yalemtsehay, M.; Beyene, P. Larvicidal effects of Jatropha curcas L. against Anopheles arabiensis (Diptera: Culicidae). MEJS 2011, 3, 52-64.

18. Juliet, S.; Ravindran, R.; Ramankutty, S.A.; Gopalan, A.K.K.; Nair, S.N.; Kavillimakkil, A.K.; Bandyopadhyay, A.; Rawat, A.K.S.; Ghosh, S. Jatropha curcas (Linn) leaf extract-A possible alternative for population control of Rhipicephalus (Boophilus) annulatus. Asian Pac. J. Trop. Dis. 2012, 2, 225-229.

19. Dimri, U.; Sharma, M.C. Effects of sarcoptic mange and its control with oil of Cedrus deodara, Pongamia glabra, Jatropha curcas and benzyl benzoate, both with and without ascorbic acid on growing sheep: Epidemiology; assessment of clinical, haematological, cell-mediated humoral immune responses and pathology. J. Vet. Med. A 2004, 55, 71-78.

20. Heal, R.F.; Rogers, E.F. A survey of plants for insecticidal activity. Lloydia 1950, 13, 89-162.

21. Sievers, A.F.; Archer, W.A.; Moore, R.H.; McGovern, E.R. Insecticidal tests of plants from tropical America. J. Econ. Entomol. 1949, 42, 549-551.

22. Solsoloy, A.D.; Solsoloy, T.S. Pesticidal Efficacy of Formulated Product J. curcas Oil on Pests of Selected Field Crops. In Biofuel and Industrial Products from Jatropha curcas and Other Tropical Oil Seed Plants, Symposium “Jatropha 97”, Managua, Nicaragua, 23-27 February 1997; pp. 216-226.

23. Singh, N.; Sushilkumar. Anti termite activity of Jatropha curcas Linn. Biochemicals. J. Appl. Sci. Environ. Manag. 2008, 12, 67-69.

24. Acda, M.N. Toxicity, tunneling and feeding behavior of the termite, Coptotermes vastator, in sand treated with oil of the physic nut, Jatropha curcas. J. Insect Sci. 2009, 9, 1-8.

25. Verma, M.; Pradhan, S.; Sharma, S.; Naik, S.N.; Prasad, R. Efficacy of karanjin and phorbol ester fraction against termites (Odontotermes obesus). Int. Biodeterior. Biodegrad. 2011, 65, 877-882.

26. Abd-Elhamid, H.F. Investigation of induced biochemical and histopathological parameters of acetonitrile extract of Jatropha curcas in albino rats. J. Egypt Soc. Parasitol. 2004, 34, 397-406.

27. Amin, M.A.; Daffalla, A.A.; Abdel Moneim, O. Preliminary report on the molluscicidal properties of Habat El Mulluk, Jatropha sp. Trans. R. Soc. Trop. Med. Hyg. 1972, 66, 805-806. 
28. Liu, S.Y.; Sporer, F.; Wink, M.; Jourdane, J.; Henning, R.; Li, Y.L.; Ruppel, A. Anthraquinones in Rheum palmatum and Rumex dentatus (Polygonaceae), and phorbol esters in Jatropha curcas (Euphorbiaceae) with molluscicidal activity against the schistosome vector snails Oncomelania, Biomphalaria and Bulinus. Trop. Med. Int. Health 1997, 2, 179-188.

29. Rug, M.; Sporer, F.; Wink, M.; Liu, S.Y.; Henning, R.; Ruppel, A. Molluscicidal Properties of Jatropha curcas against Vector Snails of the Human Parasites Schistosoma mansoni and S. japonicum: in Biofuels and Industrial Products from Jatropha curcas; Gübitz, G.M., Trabi, M., Mittelbach, M., Eds.;. Dbv-Verlag der Technischen Universität Graz: Graz, Austria, 1997; pp. 227-232.

30. Rug, M.; Ruppel, A. Toxic activities of the plant Jatropha curcas against intermediate snails and larvae of schistosomes. Trop. Med. Int. Health 2000, 5, 423-430.

31. Devappa, R.K.; Makkar, H.P.S.; Becker, K. Optimization of conditions for the extraction of phorbol esters from Jatropha oil. Biomass Bioenergy 2010, 34, 1125-1133.

32. Fagbenro-Beyioku, A.F.; Oyibo, W.A.; Anuforom, B.C. Disinfectant/antiparasitic activities of Jatropha curcas. East Afr. Med. J. 1998, 75, 508-511.

33. Adamu, S.U.; Kela, S.L.; Suleiman, M.M. Antischistosomal properties of extracts of Jatropha curcas (L) on Schistosoma mansoni infection in mice. Afr. J. Tradit. Complementary Altern. Med. 2006, 3, 37-41.

34. Suharti, S.; Wiryawan, K.G.; Tiuria, R.; Ridwan, Y.; Fitriana, S.; Sumarni, N. Effectiveness of Jatropha curcass Linn leaves as an anthelmintic for Ascaridia galli and its effect on native chicken performance. J. Anim. Sci. Technol. 2010, 33, 108-114.

35. Phowichit, S.; Buatippawan, S.; Bullangpoti, V. Insecticidal activity of Jatropha gossypifolia L. (Euphorbiaceae) and Cleome viscosa L. (Capparidacee) on Spodoptera litura (Lepidoptera: Noctuidae). Toxicity and carboxylesterase and glutathione-S-transferase activities studies. Commun. Agric. Appl. Biol. Sci. 2008, 73, 611-619.

36. Aiyelaagbe, O.O; Gloer, J.B. Japodic acid, a novel aliphatic acid from Jatropha podagrica Hook. Rec. Nat. Prod. 2008, 2, 100-106.

37. Makkar, H.P.S.; Becker, K.; Sporer, F.; Wink, M. Studies on nutritive potential and toxic constituents of different provenances of Jatropha curcas. J. Agric. Food Chem. 1997, 45, 3152-3157.

38. Devappa, R.K.; Makkar, H.P.S.; Becker, K. Jatropha diterpenes: A review. J. Am. Oil Chem. Soc. 2011, 88, 301-322.

39. Goel, G.; Makkar, H.P.S.; Francis, G.; Becker, K. Phorbol esters: Structure, biological activity, and toxicity in animals. Int. J. Toxicol. 2007, 26, 279-288.

40. Grimm, C.; Führer, E. Population dynamics of true bugs (Heteroptera) in physic nut (Jatropha curcas) plantations in Nicaragua. J. Appl. Entomol. 1998, 122, 515-521.

41. Shanker, C.; Dhyani, S.K. Insect pests of Jatropha curcas L. and the potential for their management. Curr. Sci. 2006, 91, 162-163.

42. Wahl, N.; Jamnadass, R.; Baur, H.; Munster, C.; Iiyama, M. Economic viability Jatropha curcas L. plantations in Northern Tanzania. Available online: http://www.scribd.com/doc/91571147/ 24/References (accessed on 30 November 2012). 
43. Ratnadass, A.; Ryckewaert, P.; Claude, Z.; Nikiema, A.; Pasternak, D.; Woltering, L.; Thunes, K.; Zakari-Moussa, O. New ecological options for the management of horticultural crop pests in Sudano-Sahelian agroecosystems of west Africa. Acta Hortic. 2011, 917, 85-91.

44. Wink, M.; Grimm, C.; Koschmieder, C.; Sporer, F.; Bergeot, O. Sequestration of phorbolesters by the aposematically coloured bug Pachycoris klugii (Heteroptera: Scutelleridae) feeding on Jatropha curcas (Euphorbiaceae). Chemoecology 2000, 10, 179-184.

45. Solsoloy, A.D.; Morallo-Rejesus, B. Proposed mode of action of the insecticidal principle from physic nut, Jatropha curcas L. on selected cotton insect pest. Cotton Res. J. 1994, 7, 52-53.

46. Solsoloy, A.D. Pesticidal efficacy of the formulated physic nut, Jatropha curcas L. oil on pests of selected field crops. Philipp. J. Sci. 1995, 124, 59-74.

47. Katoune, H.I.; Malam Lafia, D.; Salha, H.; Doumma, A.; Yaye Drame, A.; Pasternak, D.; Ratnadass, A. Physic nut (Jatropha curcas) oil as a protectant against field insect pests of cowpea in Sudano-Sahelian cropping systems. J. SAT Agric. Res. 2011, 9, 1-6.

48. Habou, Z.A.; Haougui, A.; Mergeai, G.; Haubruge, E.; Toudou, A.; Verheggen, F.J. Insecticidal effect of Jatropha curcas oil on the aphid Aphis fabae (Hemiptera: Aphididae) and on the main insect pests associated with cowpeas in Niger. Tropicultura 2011, 29, 225-229.

49. Agboka, K.; Mawufe, A.K.; Tamò, M.; Vidal, S. Effects of plant extracts and oil emulsions on the maize cob borer Mussidia nigrivenella (Lepidoptera: Pyralidae) in laboratory and field experiments. Int. J. Trop. Insect Sci. 2009, 29, 185-194.

50. Dowlathabad, M.R.; Sreeyapureddy, A.; Adhikari, A.; Bezawada, K.; Nayakanti, D. Pharmaceutical investigation and biopesticidal activity of Jatropha curcas L. seed oil on digestive enzymic profiles of Cnaphalocrocis medinalis (rice leaf folder) and Helicoverpa armigera (cotton boll worm). Int. Res. J. Pharm. 2010, 1, 194-200.

51. Emosairue, S.O.; Uguru, E.I. Field trial of aqueous and petroleum ether extracts of Monodora myristica (Gaertn.) dunal and Jatropha curcas L. for the control of okra flea beetles, Podagrica spp. J. Appl. Chem. Agric. Res. 1999, 6, 100-104.

52. Amaugo, G.O.; Emosairue, S.O. The efficacy of some indigenous plant extracts for the control of upland rice stem borers in Nigeria. Trop. Subtrop. Agroecosyst. 2003, 2, 121-127.

53. Sujeetha, J.A.R.P. The biological and behavioural impact of some indigenous plant products on rice white backed plant hopper (WBPH) Sogatella furcifera (Horvath) (Homoptera: Delphacidae). J. Biopestic. 2008, 1, 193-196.

54. Ratnadass, A.; Togola, M.; Cissé, B.; Vassal, J.M. Potential of sorghum and physic nut (Jatropha curcas) for management of plant bugs (Hemiptera: Miridae) and cotton bollworm (Helicoverpa armigera) on cotton in an assisted trap-cropping strategy. J. SAT Agric. Res. 2009, 7, 1-7.

55. Kshirsagar, R.V. Insecticidal activity of Jatropha seed oil against Callosobruchus maculatus (Fabricius) infesting Phaseolus aconitifolius Jacq. Bioscan 2010, 5, 415-418.

56. Adebowale, K.O.; Adedire, C.O. Chemical composition and insecticidal properties of the underutilized Jatropha curcas seed oil. Afr. J. Biotechnol. 2006, 5, 901-906.

57. Ohazurike, N.C.; Omuh, M.O.; Emeribe, E.O. The use of seed extracts of the physic nut (Jatropha curcas L.) in the control of maize weevil (Sitophilus zeamais M.) in stored maize grains (Zea mays L.). Glob. J. Agric. Sci. 2003, 2, 86-88. 
58. Jide-Ojo, C.C.; Ojo, O.O. Evaluation of the biological effects of leaf extracts of Jatropha curcas against Sitophilus zeamais (Coleoptera: Curculionidae). Electron. J. Environ. Agric. Food Chem. 2011, 10, 2166-2172.

59. Musa, A.K.; Belewu, M.A.; Muhammed-Lawal, A.; Adekola, F.O.; Olarewaju, B.O.; Ibraheem, S.O. Costs analysis and toxicity of Jatropha curcas L. on maize weevil, Sitophilus zeamais Motsch. Afr. J. Plant Sci. 2011, 5, 233-236.

60. Shelke, S.S.; Jadhav, L.D.; Salunkhe, G.N. Ovipositional and adult repellent action of some vegetables oils/extracts against potato tuber moth. J. Maharashtra Agric. Univ. 1985, 10, 284-286.

61. Shelke, S.S.; Jadhav, L.D.; Salunkhe, G.N. Ovicidal action of some vegetable oils and extract in the storage pest of potato, Phthorimea operculella Zell. Biovigyanam 1987, 13, 40-41.

62. Asmanizar, A.D.; Idris, A.B. Effect of four selected plant powder as rice grain protectant against Sitophilus zeamais (Coleoptera: Curculionidae). Sains Malays. 2012, 41, 863-869.

63. Asmanizar, A.D.; Djamin, A.; Idris, A.B. Evaluation of Jatropha curcas and Annona muricata seed crude extracts against Sitophilus zeamais infesting stored rice. J. Entomol. 2012, 9, 13-22.

64. Nabil, A.E.A.; Yasser, A.M.K. Jatropha curcas oil as insecticide and germination promoter. J. Appl. Sci. Res. 2012, 8, 668-675.

65. Onunkun, O. Evaluation of aqueous extracts of five plants in the control of fleaf beetles on okra (Abelmoschus esculentus (L.) Moench). J. Biopestic. 2012, 5, 62-67.

66. Solsoloy, A.D. Insecticidal efficacy of the formulated product and aqueous extract from physic nut, Jatropha curcas L. seed kernel oil on cotton insect pests. Cotton Res. J. 1993, 6, 28-34.

67. Silva, G.N.; Faroni, L.R.A.; Sousa, A.H.; Freitas, R.S. Bioactivity of Jatropha curcas L. to insect pests of stored products. J. Stored Prod. Res. 2012, 48, 111-113.

68. Mahfuz, I.; Khanam, L.A.M. Toxicity of some indigenous plant extracts against Tribolium confusum Duval. J. Bio-Sci. 2007, 15, 133-138.

69. Adabie-Gomez, D.A.; Monford, K.G.; Agyir-Yawson, A.; Owusu-Biney, A.; Osae, M. Evaluation of four local plant species for insecticidal activity against Sitophilus zeamais Motsch. (Coleoptera: Curculionidae) and Callosobruchus maculatus (F) (Coleoptera: Bruchidae). Ghana J. Agric. Sci. 2006, 39, 147-154

70. Boateng, B.A.; Kusi, F. Toxicity of jatropha seed oil to Callosobruchus maculatus (Coleoptera: Bruchidae) and its parasitoid, Dinarmus basalis (Hymenoptera: Pteromalidae). J. Appl. Sci. Res. 2008, 4, 945-951.

71. Ogunleye, R.F.; Ogunkoya, M.O.; Abulude, F.O. Effect of the seed oil of three botanicals, Jatropha curcas, Helianthus annus and Cocos nucifera on the maize weevil, Sitophilus zeamais (Mots). Plant Prod. Res. J. 2010, 14, 14-18.

72. Wink, M.; Koschmieder, C.; Sauerweien, M.; Sporer, F. Phorbol esters of J. curcas-Biological activities and potential applications. Available online: http://www.uni-heidelberg.de/institute/ fak14/ipmb/phazb/pubwink/1997/24.\%201997.pdf (accessed on 23 November 2012).

73. Li, J.; Yan, F.; Wu, F.H.; Yue, B.S.; Chen, F. Insecticidal activity of extracts from Jatropha curcas seed against Lipaphis erysimi. Acta Phytophylacica Sin. 2004, 31, 289-293.

74. Ratnadass, A.; Cissé, B.; Diarra, A.; Mengual, L.; Taneja, S.L.; Thiéro, C.A.T. Perspectives de gestion bio intensive des foreurs des tiges de sorgho en Afrique de l'Ouest. Insect Sci. Appl. 1997, 17, 227-233. 
75. Mengual, L. Extraction of Bioactive Substances from J. curcas L. and Bioassays on Zonocerus variegatus, Sesamia calamistis and Busseola fusca for Characterisation of Insecticidal Properties. In Biofuel and Industrial Products from Jatropha curcas and Other Tropical Oil Seed Plants, Symposium “Jatropha 97”, Managua, Nicaragua, 23-27 February 1997; pp. 211-215.

76. Georges, K.G.; Bolleddula, J.; Dalavoy, S.S.; Nair, M.G. Pest-managing activities of plant extracts and anthraquinones from Cassia nigricans from Burkina Faso. Bioresour. Technol. 2008, 99, 2037-2045.

77. Devappa, R.K.; Angulo-Escalante, M.A.; Makkar, H.P.S.; Becker, K. Potential of using phorbol esters as an insecticide against Spodoptera frugiperda. Ind. Crops Prod. 2012, 38, 50-53.

78. Li, W.; Li, J.; Li, L.; Lu, D.; Chen, F. Extraction of phorbol esters from Jatropha curcas seeds and their insecticidal activities against Pieris rapae Larvae. Chin. J. Appl. Environ. Biol. 2011, 17, 532-536.

79. Sauerwein, M.; Sporer, F.; Wink, M. Insect-toxicity of phorbol esters from Jatropha curcas seed oil. Planta Med.1993, 59, 686.

80. Jadhav, K.B.; Jadhav, L.D. Use of some vegetable oils, plant extracts and synthetic products as protectants from pulse beetle, Callosobruchus maculatus Fabr. in stored gram. J. Food Sci. Technol. 1984, 21, 110-113.

81. Solsoloy, A.D.; Morallo-Rejesus, B. Effect of the insecticidal principle from physic nut, Jatropha curcas L. on the cotton flower weevil Amorphoides lata Motsch. Cotton Res. J. 1991, 4, 12-22.

82. Cobbinah, J.R.; Tuani, G.K. Antifeedant effect of Jatropha curcas L. seed oil and extracts on the variegated grasshopper, Zonocerus variegatus L. (Orthoptera: Acrididae). J. Univ. Sci. Technol. 1992, 12, 136-139.

83. Wink, M. Production and Application of Phytochemicals from an Agricultural Perspective. In Phytochemistry and Agriculture; van Beek, T.A., Breteler, H., Eds.; Clarendon Press: Oxford, UK, 1993; Volume 34, 171-213.

84. Isman, M.B. Botanical insecticides, deterrents, and repellents in modern agriculture and an increasingly regulated world. Annu. Rev. Entomol. 2006, 51, 45-66.

85. Devappa, R.K.; Makkar, H.P.S.; Becker, K. Biodegradation of Jatropha curcas phorbol esters in soil. J. Sci. Food Agric. 2010, 90, 2090-2097.

86. Jain, C.; Trivedi, P.C. Nematicidal activity of certain plants against root-knot nematode, Meloidogyne incognita infecting chickpea. Ann. Plant Prot. Sci. 1997, 5, 171-174.

87. Kalaiarasan, P.; Senthamarai, M.; Ramesh, D.; Sudheer, M.J. Jatropha: An efficient organic amendment for the management of root-knot nematode, Meloidogyne incognita in tomato. Indian J. Nematol. 2007, 37, 115-118.

88. Umeh, A.; Ndana, R.W. Effectiveness of Jatropha curcas and Jatropha gossypiifolia plant extracts in the control of Meloidogyne incognita on okra. Int. J. Nematol. 2010, 20, 226-229.

89. Bhagat, R.B.; Kulkarni, D.K. Evaluation of larvicidal and antifeedant potential of three Jatropha species against Spodoptera litura (Lepidoptera: Noctuidae) and two predators (Coleoptera: Coccinellidae). Ann. Biol. Res. 2012, 3, 2911-2916.

90. Reddy, G.V.M.; Girish, R.; Uma, M.S.; Srinivas, N. Acaricidal activity of aqueous extracts from leaves and bark of cinnamomum and jatropha against two spotted spider mite, Tetranychus urticae Koch. Karnataka J. Agric. Sci. 2009, 22, 693-695. 
91. Devappa, R.K.; Makkar, H.P.S.; Becker, K. Jatropha toxicity: A review. J. Toxicol. Environ. Health 2010, 13, 476-507.

92. Devappa, R.K.; Maes, J.; Makkar, H.P.S.; De Greyt, W.; Becker, K. Quality of biodiesel prepared from phorbol ester extracted Jatropha curcas oil. J. Am. Oil Chem. Soc. 2010, 87, $697-704$.

93. Roach, J.S.; Devappa, R.K.; Makkar, H.P.S.; Becker, K. Isolation, stability and bioactivity of Jatropha curcas phorbol esters. Fitoterapia 2012, 83, 586-592.

94. Martin, T.; Assogba-Komlan, F.; Sidick, I.; Ahle, V.; Chandre, F. An acaricide-treated net to control phytophagous mites. Crop Prot. 2010, 29, 470-475.

95. Rai, M.K. In vitro evaluation of medicinal plant extracts against Pestalotiopsis mangiferae. Hindustan Antibiot. Bull. 1996, 38, 53-56.

96. Thangavelu, R.; Sundararaju, P.; Sathiamoorthy, S. Management of anthracnose disease of banana caused by Colletotrichum musae using plant extracts. J. Hortic. Sci. Biotechnol. 2004, 79, 664-668.

97. Wei, Q.; Liao, Y.; Chen, Y.; Wang, S.H.; Xu, Y.; Tang, L.; Chen, F. Isolation, characterization and antifungal activity of $\beta$-1,3-glucanase from seeds of Jatropha curcas. S. Afr. J. Bot. 2005, 71, 95-99.

98. Ogbebor, N.O.; Adekunle, A.T.; Enobakhare, D.A. Inhibition of Colletotrichum gloeosporioides (Penz) Sac. causal organism of rubber (Hevea brasiliensis Muell. Agr.) leaf spot using plant extracts. Afr. J. Biotechnol. 2007, 6, 213-218.

99. Saetae, D.; Suntornsuk, W. Antifungal activities of ethanolic extract from Jatropha curcas seed cake. J. Microbiol. Biotechnol. 2010, 20, 319-324.

100. Makun, H.A.; Anjorin, S.T.; Adeniran, L.A.; Onakpa, M.M.; Muhammad, H.L.; Obu, O.R.; Agbofode, Y.V. Antifungal activities of Jatropha curcas and Ricinus cumunis seeds on Fusarium verticilliodes and Aspergillus flavus in yam. J. Agric. Biol. Sci. 2011, 6, 22-27.

101. Rahman, M.; Ahmad, S.H.; Mohamed, M.T.M.; Rahman, M.Z.A. Extraction of Jatropha curcas fruits for antifungal activity against anthracnose (Colletotrichum gloeosporioides) of papaya. Afr. J. Biotechnol. 2011, 10, 9796-9799.

102. Byers, R.A.; Mangan, R.L.; Templeton, W.C., Jr. Insect and slug pests in forage legume seedlings. J. Soil Water Conserv. 1983, 38, 224-226.

103. Donigian, A.S.; Carsel, R.F. Modeling the impact of conservation tillage practices on pesticide concentrations in ground and surface waters. Environ. Toxicol. Chem. 2009, 6, 241-250.

104. Ratnadass, A.; Randriamanantsoa, R.; Douzet, J.M.; Rakotoalibera, H.; Andriamasinoro V.; Rafamatanantsoa, E.; Michellon, R. Evaluation des risques liés au traitement de semences contre les attaques d'insectes terricoles sur riz pluvial à Madagascar et d'alternatives biologiques aux molécules de synthèse. In ORP Conference, Montpellier, QC, Canada, 27-30 August 2012.

(C) 2012 by the authors; licensee MDPI, Basel, Switzerland. This article is an open access article distributed under the terms and conditions of the Creative Commons Attribution license (http://creativecommons.org/licenses/by/3.0/). 